\title{
The knowledge of disembodied souls: Epistemology, body, and social embeddedness in the eschatological doctrine of later sixteenth-century German Lutherans ${ }^{1}$
}

\author{
GÁBOR ITTZÉS \\ Károli Gápár University
}

\begin{abstract}
In the wake of their rejection of purgatory Protestants had to rethink their eschatological views. The German Lutherans of the latter half of the sixteenth century developed a robust doctrine of the last things, including a teaching on what departed souls know prior to the resurrection. Following an overview of the sources and a brief reconstruction of the overall locus, this article focuses on an analysis of what and how disembodied souls are claimed to know. The evidence holds some surprises. First, while more than lip-service is certainly paid to the ways of knowing God, the authors' real interest lies in the exploration of interpersonal relationships. Their primary concern is how other human beings, whether still on earth or already departed, may be known and what may be known about them. The implications are threefold. Knowledge of God and knowledge of human beings-ultimately, knowledge of self-are intertwined. Anthropology takes centre-stage, and ontology is thus superseded by epistemology. In all this, the body is never relinquished. The apparently unconscious importation of sensory language and conceptualisation of sense-based experience permeate the discussion of ostensibly disembodied knowledge. Knowing, for our authors, is ultimately a function of the body even if this means 'packing' bodily functions into the soul. In this doctrine, which may have had its roots in patristics but which has also demonstrably absorbed impulses from popular religion, knowledge of God is not only deeply connected with individual identity but also exhibits indelible social features and is inseparable from the (re)constitution of community.
\end{abstract}

Keywords: 16th century, Lutheranism, resurrection, epistemology, departed souls

1 Research for this paper was supported by the Bolyai János Research Scholarship of the Hungarian Academy of Sciences. 
When the Protestant Reformation rejected the doctrine of purgatory as unbiblical, ${ }^{2}$ the fate of the human person between the death and resurrection of the body had to be fundamentally rethought. The early Reformers had tackled the issue, ${ }^{3}$ but it is not until the latter half of the sixteenth century that we can speak of a new Lutheran consensus on the question. Exploring the emerging new teaching, in this paper I shall focus on how and why questions of epistemology became central to early modern evangelical discussions of individual eschatology. I shall argue that in clarifying what and how disembodied individual souls know, social and bodily aspects of knowledge emerged as decisive elements.

If this conclusion seems paradoxical, we would do well to recall David Tripp's warning against the temptation of 'assum[ing] that the Protestant Reformation dissolved an over-arching unity prevailing throughout Christendom'. It was in fact against a 'background of a dissolving ecclesial body that both "Protestant" and "Catholic" reformations reaffirmed the claim of God upon the whole body - of the individual, of the church, of society at large' (1997, 131f.). Examining the responses of influential early Reformers to this challenge, Tripp finds in their work 'a discovery ... of a sense of body in the person [and] in the general community' $(1997,147)$. In what follows, I shall show how that 'sense of body' was developed in a particular (eschatological) context by the next two generations of Lutheran thinkers. In doing so, I shall be interested not so much in what the early modern texts have to say about the post-mortem state of the soul per se as in what they reveal about the presuppositions, commitments, and concerns of their authors. I shall pay more attention to the writers' actual performance, developing a 'sense of body' at different levels, than to their ostensible focus on the disembodied state.

Since my larger argument is based on a reconstruction of historical developments, I shall begin with the sources. Thus, in turning first to that body (of literature) which allows conclusions about other senses of the term,

2 On the origins and rise of the doctrine, see Le Goff's now classic study The Birth of Purgatory (1984). For a defence of its biblical origins, see Anderson (2011), and for a recent assessment of its fortunes in the sixteenth and seventeenth centuries, Malý (2015).

3 The reconstruction of Luther's views is a thorny issue, much debated over the last century, that cannot be discussed here. See Thiede (1982 and 1993) for a programmatic exposition, and Lohse (1999, 325-32) for a more cautious overview. Melanchthon offered a more sustained and systematic treatment of the question in the concluding chapter of his De anima commentary (1544, 303-15 and 1988, 284-9), on which see also Frank (1993). For a recent discussion of the Wittenberg Reformers' early attacks on purgatory, with attention to the bodily senses of sight and hearing, see Evener (2015). 
I shall provide a sketchy overview of the texts that underlie my investigation. The first set of material questions to ask of the sources will concern the knowledge of blessed souls in the disembodied state. From this emerges the importance of disembodied souls recognising each other as persons in the interim state. Once the review of the historical material is complete, more systematic reflections can be offered on our findings concerning the bodily aspects and social embeddedness of knowledge in the eschatological thought of the later sixteenth-century exponents of evangelical Christianity.

\section{A body of literature}

The literary corpus I am discussing is quite substantial. ${ }^{4}$ It consists of texts that were written over a generation but remained in print for more than half a century. The most successful titles were frequently reprinted, with the whole corpus comprising some forty editions, stemming from territories as far apart as Strasbourg and Berlin, or Dresden and Hamburg, and even Copenhagen. Taken together, these works represent the bulk of the Lutheran lands of the Empire. The corpus is also quite representative in terms of social stratification. It is true that most, but not all, authors were ordained ministers, yet their ecclesiastical status differed considerably from simple country parsons to general superintendents and professors of theology, sometimes of international stature. ${ }^{5}$ The works were written in, or translated into, the vernacular. Their physical format also suggests that

\footnotetext{
4 The works include, in chronological order of their first publication, Melchior Specker's Vom Leiblichen Todt (1560), Andreas Musculus's Gelegenheit/ Thun vnd Wesen der Verstorbenen (1565), Basilius Faber's Tractetlein von den Seelen der verstorbenen (1569), Johannes Garcaeus Jr's Sterbbüchlein Darin Von den Seelen/ jrem ort/ stande/ thun und wesen / aller Menschen/bis an den Jüngsten tag/aus Gottes wort vnd der lieben Veter Schrifften/ warhafftiger bericht (1573), Martin Mirus's Sieben Christliche Predigten (preached in 1575, first printed in 1590), David Chyträus Sr's De morte et vita aeterna (1581-1582, GT 1590-1591), Moses Pflacher's Die gantze Lehr Vom Tod vnd Absterben des Menschen (1582), Gregor Weiser's Christlicher Bericht/ Von Vnsterbligkeit und Zustand der Seelen nach jhrem Abschied/ Vnd letzten Hendeln der Welt (1588), and Bartholomaeus Frölich's Seelen Trost/ Das ist/ [C]hristlicher bericht vom Zustande vnd Glück der lieben Seelen/ in jener Welt/ biß an den jüngsten Tag (1590). Of course, further works could be added to the list, but it is my contention that they would not significantly alter the emerging picture.

5 Basic biographical information is available on most in standard handbooks: Chyträus: ADB 4:254-6 (NDB 3:254), BBKL 1:1021-122, DBE 2:344, LThK³ 2:1197, RGG 2:377f. (RPP 3:202); Faber: ADB 6:488-90, DBE $3: 199$; Frölich: BBKL 2:139; Garcaeus: ADB 8:370f., DBE ${ }^{2}$ 3:682; Mirus: ADB 22:1; Musculus: ADB 23:93f. (NDB 18:626f.), BBKL 6:380f., DBE² 7:322, LThK $^{3}$ 7:542, RGG 5:1593 (RPP 8:619); Pflacher: BBKL 7:421-3, DBE 2 7:802, RGG4 6:1244 (RPP 10:26). While Specker appears in DBA (I:966.317, II:595.158), I have not been able to find any external information on Weiser (cf. n. 21, below).
} 
they were intended for a general readership. ${ }^{6}$ Their genres vary, and many works - sermon sequences, catechisms, devotional pieces - were meant for a lay audience. What makes this body of literature especially interesting is that later authors often drew on their predecessors, and their dependence, if rarely acknowledged, ${ }^{7}$ can be demonstrated by a careful analysis of the texts. ${ }^{8}$

While differing in some detail, all texts agree ${ }^{9}$ that the soul survives the death of the body in a wakeful state. It is carried either by angels into God's hands to be with Christ or by devils to hell. Both places have a variety of names such as heaven, paradise, Abraham's bosom, land of the living, and many more, ${ }^{10}$ but no middle ground is admitted. Purgatory is dismissed. Blessed souls are redeemed from all suffering and enjoy peace and rest while worshipping and contemplating God. Both aspects, the happy state and worship of the blessed, are described in some detail. Another widely held and extensively argued claim is that souls cannot appear on earth, although the devil may abuse their shape. ${ }^{11}$ The state of the damned is described in similar but opposite terms. Generally, there is less interest in the damned, and authors spend more time on the happiness in store for the faithful.

It is in this general context that discussions of more specific epistemological details occur. Unsurprisingly, the approach our writers take is profoundly scriptural. Whatever points they make, authors routinely argue from biblical evidence. But they bring their own presuppositions to the text, and it is part of my goal to uncover what their exegetical and constructive performance reveals about their prior commitments and underlying convictions about the social and bodily preconditions of knowing God, the self, and the other.

\footnotetext{
6 The books were often issued in the relatively small octavo size (sixteen pages or eight leaves - hence the name - to the printing sheet), suggesting affordable publications.

7 Weiser's open use of Mirus's Regensburg Sermons is atypical. He also refers to Faber's 'golden booklet' ('gülden Büchlein'; 1588, B13'), cf. Brady (1971) 828.

8 I have developed this argument in a series of papers (Ittzés 2015a; 2015b; 2016) and will assume the validity of their conclusions as I explore thematic connections between individual works in the selected corpus.

9 For details briefly summarised here, see Chyträus (1592) C $5^{\mathrm{v}}-\mathrm{D} 3^{\mathrm{r}}$; Faber (1572) a $1^{\mathrm{r}}-\mathrm{b} 2^{\mathrm{v}}$,

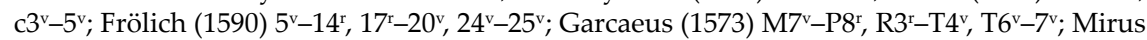
(1590) O2 $2^{\mathrm{r}}-3^{\mathrm{v}}$; Musculus (1565) C2 $2^{\mathrm{r}}-5^{\mathrm{r}}\left(\mathrm{cf}^{\mathrm{r}} \mathrm{D} 3^{\mathrm{v}}-4^{\mathrm{r}}\right), \mathrm{C}^{\mathrm{r}}-8^{\mathrm{v}}$; Pflacher (1589) 272-4; Specker (1560) $256^{\mathrm{v}}-265^{\mathrm{v}}, 269^{\mathrm{r}}-275^{\mathrm{r}}, 278^{\mathrm{v}}-287^{\mathrm{r}}, 289^{\mathrm{r}}-291^{\mathrm{v}}$; Weiser (1588) 23-8, 31f.

10 This, indeed, is a big issue for early modern authors, and their discussions of this point provide extensive philological ground to argue the interrelatedness of their texts.

11 This is a major topic in and of itself, requiring independent treatment, which I have provided elsewhere (Ittzés 2014). Cf. also Evener 2015.
} 


\section{Knowledge of the blessed souls in the disembodied state}

Numerous texts in the corpus include an analysis, often formally demarcated, of what and how disembodied souls know, and others draw similar conclusions in passing. The fullest discussion may be found in a close-knit group of texts stemming from Melchior Specker's Vom leiblichen Todt (1560, $\left.266^{\mathrm{r}}-269^{\mathrm{r}}, 287^{\mathrm{r}}-288^{\mathrm{v}}\right){ }^{12}$ The subject matter of Specker's chapters 7 and 11 is the knowledge of the righteous and the damned, respectively. Specker develops the former in more detail. He asserts that the blessed souls recognise the Trinity and the secrets of God's kingdom, but then, drawing on the parable of Lazarus and Dives (Luke 16:19-31) and on the episode of the transfiguration (Luke 9:28-36), ${ }^{13}$ he spends considerably more time elaborating on various aspects of life on earth after the soul's departure as the object of the departed soul's knowledge. The Trinity and God's lordship may be the apex of human cognition and therefore deserve pride of place on the list, but the bulk of Specker's attention is devoted to literally more mundane-and interpersonal-issues.

After a review of what is known, he turns to the problem of how disembodied souls gain knowledge. He comes up with an Augustinian answer. The bishop of Hippo suggests in paragraph 18 of On Care to Be Had for the Dead that before the resurrection of the body departed souls may obtain information about events in this life from newly arriving souls, from angels, or by God's direct revelation (cf. NPNF ${ }^{1}$ 3:548). That theory will be widely accepted with virtually no alternative offered in the whole corpus. Unimaginative as this straightforward reliance on patristic material is, its basic orientation is worth noting. Specker, and his later colleagues, are not interested in explaining how an individual's mind works in obtaining, or producing, knowledge. Instead, they focus on its social embeddedness. Even in the hereafter, knowledge is largely not immediate but mediated through a network of others. Thus, both in the what and the how of knowing, interpersonal aspects predominate, although the divine element, both as object and source of knowledge, is also recognised.

When we compare Basilius Faber's Tractetlein von den Seelen der ver-

12 Specker is most closely followed by Basilius Faber's Tractetlein von den Seelen der verstorbenen (1572) and Johannes Garcaeus Jr's Sterbbüchlein (1573); cf. Ittzés (2015b; 2016). Vom Leiblichen Todt is the most successful work of its author, a by now largely forgotten Strasbourg professor of theology. It is a bulky florilegium excerpting texts from the Bible, the church fathers, medieval theologians, and contemporary authors. Organised thematically, its three parts deal with bodily death and its names, the corpse and burial, and the fate of the soul in the Zwischenzustand.

13 Both Specker and his followers cite all three synoptic gospels by chapter (Matthew 17, Mark 9, Luke 9), irrespective of the fact that the relevant detail, that Moses and Elijah know that Jesus will die in Jerusalem (v. 31), is Lukan Sondergut. 
storbenen $^{14}\left(1572, \mathrm{~b}^{\mathrm{r}}-7^{\mathrm{r}}\right)$ and Johannes Garcaeus Jr's Sterbbüchlein ${ }^{15}$ (1573, $\mathrm{P} 8^{\mathrm{r}}-\mathrm{R} 3^{\mathrm{r}}, \mathrm{T} 4^{\mathrm{v}}-\mathrm{6}^{\mathrm{r}}$ ) with Specker's work, we see that they followed him quite closely. The content of their positions resembles his, and the structure of their argumentation also exhibits parallels. Both later authors adapt the Augustinian position on how souls gain information, and Garcaeus even expands the discussion of the central topic that souls know what is going on in this world. There is, however, a subtle yet significant shift in their focus that should not go unnoticed. The subjecthood of the other is acquiring growing importance among the interpersonal aspects of knowledge.

In the last section of chapter 7 Specker briefly asserts that disembodied souls 'recognise each other. [...] Thereby is the foolishness of those people openly repudiated who $[\ldots]$ hold that souls $[\ldots]$ do not recognise $[\ldots]$ each other. ${ }^{16}$ This is hardly more than a cursory reference. Faber then transforms the related issue of blessed souls thinking of and caring for their relatives into a major topic, and devotes nearly half a chapter to it. Garcaeus goes even further, and treats the matter in a whole new chapter. The increased space assigned to the question obviously mirrors a growing interest in it. When we look at the broader picture, we can register a similar tendency. The topic is largely absent from Andreas Musculus's Gelegenheit/ Thun vnd Wesen der Verstorbenen $\left(1565, \mathrm{C}^{\mathrm{v}}-5^{\mathrm{r}}\right){ }^{17}$ However, in texts after the late $1560 \mathrm{~s}$ this is precisely the most important, if not the only, epistemological issue.

In the Sieben Christliche Predigten, originally preached at the Diet of Regensburg in 1575, Martin Mirus ${ }^{18}$ articulates the thesis concisely:

Without doubt they [the righteous souls] also know each other among them-

14 Faber, remembered as one of the most influential educators in sixteenth-century Saxony and renowned for his Latin dictionary, is the only layman among our authors. The Tractetlein was a later addition to an immensely popular eschatological piece which went through some twenty editions (cf. Ittzés 2016).

15 Trained in Wittenberg, Garcaeus rose to be a professor of theology and superintendent. His contribution to the natural sciences was also significant. With probably four editions, the Sterbbüchlein, on the nature and fate of the soul, was his most successful theological work (cf. Ittzés 2015b, 336-9).

16 '..das sie einander kennen / ... Dardurch würt deren leüten thorheyt offentlicht gestrafft / die ... halten / die Seelen ... erkennen ... einander nit' (Specker 1560, 269'). The topic appears more emphatically in the otherwise shorter chapter 11 on the knowledge of the damned souls (Specker 1560, 288v).

17 Drawing chiefly on Wisdom 5 and Luke 16, his logic is vaguely reminiscent of Specker's points about both the damned and the righteous, but here we find them in a rather embryonic form, with not much explicit reflection on knowledge. Epistemologically, Musculus seems a little more interested in the damned, but even this is not very much, and the question as to whether souls recognise each other is not raised.

18 Court preacher to the Elector of Saxony, Mirus was a prominent theologian of his age and an author of the Formula of Concord, an epochal document that successfully settled decades of intra-Lutheran debates. His anti-Catholic Regensburg Sermons circulated widely in manuscript form before their first printing fifteen years later (Ittzés 2015a, 64-6). 
selves and live together in true love and friendship, also have fervent love and inclination towards their beloved who still sojourn on earth, enquire about their state from the dear angels and among themselves from those who are newly arrived from there. ${ }^{19}$

The introductory protestation might be a clue that this view was not yet entirely self-evident. ${ }^{20}$ In Christlicher Bericht (1588) Gregor Weiser ${ }^{21}$ takes a clue from Mirus and quotes the relevant passages. ${ }^{22}$ When he reflects on the occupation of blessed souls, Weiser makes no mention of their knowledge, and nor does he turn any aspect of epistemology into an independent question of his catechism $(1588,23 \mathrm{f} ., 27,32)$. Nevertheless, there is a paragraph by Mirus in the concluding part of the fourth Regensburg sermon in which he comforts those bereft of a family member with the assurance that they are not altogether lost but will be seen again on the 'Dies restitutionis omnium[.] ${ }^{23}$... That is why we should gird our souls with patience in the meantime and console ourselves with the same hope. ${ }^{24}$ The entire passage is cited by both Weiser $(1588,29)$ and Pflacher $(1589,276)$.

19 'On zweiffel kennen sie sich auch unter einander/ vnd leben beysamen / in warer Lieb vnd Freundschafft / haben auch noch sehnliche Liebe vnd Neigung gegen den jrigen/ so noch auff Erden wallen/ erkündigen sich jres zustandes bey den lieben Engelein / vnd vnter jnen selbst bey denen so newlichst von hinnen komen/' (Mirus 1590, O2v').

20 Note the unmistakeable references to De cura even though Augustine is not mentioned.

21 Little is known of Weiser except that he was a village parson near Meißen, Saxony, and flourished between 1577-1582. Christlicher Bericht saved his name from oblivion. Organised in Q\&A format, the work heavily draws on prominent sixteenth-century Lutheran theologians to discuss eschatological issues (Ittzés 2015a, 62f.).

22 On Weiser's general dependence on Mirus, see Ittzés (2015a) 72-9. Moses Pflacher, another author who owes much to Mirus, greets the epistemological question in silence in Die gantze Lehr Vom Tod vnd Absterben des Menschen (1589), while David Chyträus, drawing on the story of the transfiguration, clearly implies the standard view in Christlicher, Tröstlicher und in Gottes Wort gegründter unterricht $\left(1592, \mathrm{D} 1^{\mathrm{v}}\right)$, but he places the emphasis elsewhere.

23 It might be suggested that this line of interpretation diverges significantly from Specker and his immediate followers, in that it makes personal recognition a privilege of resurrected humans, but I find this argument unconvincing. The textual counterevidence is delivered by Mirus, who does say that souls recognise each other before judgement day. (The problematic passage is offered as an application of the foregoing teaching that souls will recognise each other, on which premise the questionable clause thus depends for its interpretation.) The explanation lies in the fact that early modern authors did not see the post-mortem and postresurrection existence in sharp juxtaposition - a point to which I will return in the next section. 24 'Dies restitutionis omnium, ... Da wollen wir einander in freuden wider sehen / vnd sol vns kein Todt in ewigkeit mehr scheiden/ Drumb wir mitler weile sollen vnsere Seelen mit gedult fassen / vnd vns derselben seligen hoffnung trösten' (Mirus 1590, O4r). 
In the Seelen Trost Bartholomaeus Frölich ${ }^{25}$ treats the topic in a grand fashion, making the question 'Whether we will also know each other in the other world' the subject of his fifth chapter. ${ }^{26} \mathrm{He}$ responds to what he regards as a widespread popular misconception that only cousins and godparents ${ }^{27}$ will recognise each other in the hereafter. Interestingly, he takes a broad epistemological sweep to construct a well-founded answer, and covers much the same ground as Specker in the process. Here we see the consummation of the development that began in the early 1560s in the sense that we have now returned full circle to the rich epistemological picture of Vom leiblichen Todt, but this time the disembodied souls' personal recognition is not a tangentially treated minor point at the end, but constitutes the overarching problem and framework within which the entire discussion is situated..$^{28}$

Sixteenth-century German Lutheran authors thus reflected on epistemological questions while thinking through the fate of the human soul after the death of the body. Disembodied souls' knowledge of the divine ${ }^{29}$ is certainly not passed over in silence, but social aspects of knowledge seem to command even greater attention among the writers. Within this matrix, individuals' recognition of each other emerged as a major concern of early modern thinkers. It is to this question that we must now turn.

\section{Personal recognition and the blurred line between the interim state and post-resurrection life}

Most texts in the selected corpus affirm that departed souls recognise each other in the hereafter. The level of their engagement with the question varies considerably, and the most detailed discussion is provided by Johannes Garcaeus $\left(1573, \mathrm{P}^{\mathrm{r}}-\mathrm{R} 3^{\mathrm{r}}\right)$. He enumerates no fewer than ten arguments for the sweeping thesis that the blessed souls know all who fall asleep in Christ, that is, in the community of the righteous everyone knows everyone else personally. First, Peter immediately recognised Moses and Elijah

25 Frölich is virtually unknown except as a hymn writer who once enjoyed considerable popularity. Silesian by birth, he served as pastor in a small town in Brandenburg. Seelen Trost, essentially an ars moriendi piece, is one of only two books by him.

26 'Ob wir einander in jener Welt auch kennen werden' $\left(1590,81^{\mathrm{v}}-89^{\mathrm{v}}\right)$.

27 'Gefettern vnnd Paten' (Frölich 1590, 81ํ).

28 It must be noted, however, that it remains undecided throughout Frölich's chapter whether the argument pertains to the post-resurrection or to the post-mortem state.

29 On the medieval background and the controversy concerning beatific vision, see Bynum (1995), esp. 279-317. 
with his eyes 'weighed down with sleep' on the mount of transfiguration (Luke 9:32-33). ${ }^{30}$ Second, Christ was recognised by his disciples when he appeared in his glorified body after Easter. Third, Adam recognised each animal when God had brought them before him to name them, and he needed no introduction to Eve (Gen 2:19-23). Fourth, Elizabeth and 'little Johnny' ('Henselein'; 1573, Q7r) in her womb recognised Jesus when Mary came to visit them, as did the Baptist again at the Jordan, although he had never seen Jesus before (Luke 1:39-45 and Matt 3:13-15). ${ }^{31}$ Fifth, Abraham knows both Lazarus and the rich man (Luke 16:25-31). Sixth, the godless recognise the righteous whom they have oppressed (Wis 5:1-5). Seventh, we know, hear, and see our friends and acquaintances in this life. Eighth, we will see God and the angels face to face, so how much more shall we see the elect who are but human beings. Ninth, if the 'wise shall shine like the brightness of the sky' (Dan 12:3), there will be a difference in glory among the elect, which is impossible unless God's exceptional servants ('wunderleute'; 1573, Q8v) are recognised. Tenth and last, the righteous with Christ will recognise both themselves and their Saviour (John 17:24-25). ${ }^{32}$ Garcaeus appends three unnumbered sets of further prooftexts to this list. The first is on the new Jerusalem, ${ }^{33}$ the second includes Jeremiah's and Paul's prophecies about an immediate and complete knowledge of God, ${ }^{34}$ and the third is a general allusion to promises of our future Christiform shape. ${ }^{35}$ The point in each case is that perfect knowledge includes knowing and recognising one another.

The line between 'arguments' and 'prooftexts' is thus fluid; all but the seventh argument are scripture-based. The overarching logic, with the exception of a few items, is always the same, namely, that the existence of the righteous in the hereafter is a perfected form of their current being. To borrow a technological metaphor, their new life is 'backwards compatible' with their earthly life: everything they were capable of do-

30 Garcaeus simply alludes to the story without citing any reference, but the sleepy eyes again mark out Luke, cf. 'mit schlefferigen augen' (Garcaeus 1573, Q5') and Luke 9:32.

31 Note that in Garcaeus's reconstruction, probably developing Luke 1:45, Elizabeth is supposed to have been providentially aware of the whole angelic message given to Mary (Luke 1:35).

32 In the original, the locus is cited as John 7 (Garcaeus 1573, Q8 ${ }^{\mathrm{v}}$ ).

33 Isa 65:17-20, 2 Pet 3:13, and Rev 21:1-2.

34 Jer 31:33-34 and 1 Cor 13:9-12.

35 Garcaeus might have passages like Rom 8:29, 1 Cor 15:49 or Phil 3:21 in mind, and, since he evokes the witness of Paul, Peter, and John $\left(1573, \mathrm{R}^{\mathrm{v}}\right)$, also 2 Pet 1:4 and 1 John 3:2. His actual wording is closest to Phil 3:21. 
ing here, they will retain the power to do-and even surpass - there. ${ }^{36}$ If such and such is the case in the examples cited, how much more so in our improved state! ${ }^{37}$

Garcaeus sets out to discuss a feature of the interim state (souls recognising each other), yet many of the arguments, not to mention the concluding sets of biblical excerpts, may, and some do, pertain to life eternal after the general resurrection. Disregarding several ambiguous items, the second and the ninth arguments are practically impossible to interpret regarding the Zwischenzustand. Jesus was recognised in his clarified body (\#2) to which the departed souls have not yet attained, and the Danielic verse (\#9) is part of a resurrection prophecy. Even if we allow that the New Jerusalem might be interpreted to denote the righteous souls' interim abode, as in Specker $\left(1560,233^{v}-234^{v}\right)$, the assumption of a glorified body like Christ's (Phil 3:21) cannot commence before the general resurrection. In drawing the desired conclusion from a given example, Garcaeus also frequently speaks of eternal life, and never specifically of souls. In other words, while epistemology is a helpful test case to examine qualities of the interim state, the arguably most important aspect of knowledge after death - the individual recognition of other persons - does not sharply distinguish between the pre- and post-resurrection states.

There is only one passage in the whole chapter where Garcaeus seems to differentiate between various stages of knowing. He draws this conclusion from the third argument:

Adam, through God's created image in him, likewise had knowledge and recognition of all things; nor can his bodily natural deep sleep hinder him in the same in his complete righteousness, wisdom and understanding. How much more shall we have such wisdom, recognise each other [and] converse with each other in life eternal, since in the state where we possess our glory

\footnotetext{
36 This is the meaning of backwards compatibility. If, e.g., a new version of a word processor can handle formats of an older software, it is said to be backwards compatible with its predecessor (which, by contrast, may not be able to open files in the native format of the new version).

37 Note that it is of secondary significance what constitutes the inferiority of the examples cited in the arguments over against the future perfection. Reference cases may be taken equally from the pristine condition of creation, from the sinful world, or even from the godless in the hereafter. In one respect or another the state of the blessed souls will surpass each reference case and, given the assumption of backwards compatibility, will include features at least as good as those described in the example.
} 
eternally without loss and danger we shall receive much greater glory [and] more complete clarity than Adam [originally had]. ${ }^{38}$

Here we see three distinct states delineated, with a fourth implied. The four states include created perfection, fallen existence, the interim state between death and resurrection, and finally life eternal after the general resurrection. The second stage, earthly life as we know it after the fall, is only implicitly present in the passage, ${ }^{39}$ but the other three are explained. First, prelapsarian Adam had perfect knowledge of all things. Adam in the (third) post-mortem state (during 'his bodily natural deep sleep') has again recovered his undiminished epistemic powers. Presumably, the same applies to us as well, although this is not made explicit. This is a relatively short but densely packed sentence that deserves a closer look. The Zwischenzustand is identified with the help of the metaphor of sleep, and it is qualified by three adjectives. It is deep: death is analogous to, but is even 'more so' than, sleep. It is nonetheless natural because Adam is ultimately numbered among the righteous, for whom Christ has tamed death. Finally, it is bodily or, literally, fleshly ('fleischlicher'): sleep is predicated of Adam the whole person, but the first adjective helps avoid any misunderstanding. Sleep is only to be understood of his body. His soul, by implication, is awake, and indeed enjoys its epistemic functions to the full, purged of the noetic effects of sin ('in his complete ... wisdom and understanding') ${ }^{40}$ The fourth epistemic state is introduced with a comparison that signals a contrast: 'How much more...' The contrast is drawn in terms of eternality and immunity to change on the one hand, and of perfection (glory and clarity $)^{41}$ on the other. Eternal life is superior both because of the inherent qualities of our knowing and because there will be no external factors limiting it either. As the additional

38 'Also hat Adam/ durch Gottes bilde / in jm erschaffen/gehabt die wissenschaft vnd erkentnis aller dinge / in seiner volkomenē gerechtigkeit / weisheit vnd verstand/mus jn daran auch nichts hindern/ sein fleischlicher natürlicher tieffer schlaff. Wie viel mehr werden wir im ewigen leben solche weisheit haben / einander kennen/mit einander reden /da wir viel höher herrlicher/vollkomener klarheit empfangen werden/ denn Adam / in dem stand/da wir vnser herrligkeit on verlust vnd gefahr ewig besitzen' (Garcaeus 1573, Q6 ${ }^{\mathrm{r}}$ ).

39 Garcaeus will return to this in the seventh argument.

40 What Garcaeus successfully invokes here in a few words is an entire tradition of theological argumentation. Underlying his choice of adjectives is a Christian interpretation of the sleep metaphor, which itself goes back to Old Testament and Classical sources. That he can effectively do so- and can expect his audience to understand the import of his concise formulation - is a testimony to the strength of the later sixteenth-century consensus on this point. For more on the uses of the sleep metaphor in the corpus, see Ittzés (2014).

41 Here we can hear faint echoes of the medieval 'four dowries' -i.e. perfections of the glorified body - tradition, on which see Bynum (1995) 131f., 235f. and passim. 
words supplied in my translation above have already indicated, the comparison, on my reading, is not between the post-resurrection state and the Zwischenzustand, but between life eternal and Adam's original condition. Promising as the three- (or four)fold structure of the passage is, it ultimately reveals nothing of an appreciable epistemological distinction between the interim state and life after judgement day.

An alternative approach is offered by Basilius Faber. A key difference between him and Garcaeus is that he rather presupposes than seeks to establish that souls will recognise each other. Faber's thesis is the further point that even before meeting in the hereafter, disembodied souls remember and think of their relatives $\left(1572, b 4^{v}-6^{r}\right)$. That thesis surely entails the conviction that souls recognise each other, for what would be gained by confirming their care and concern for others if the longed-for acquaintances were not recognised upon joining the company of the righteous souls? The advantage of Faber's approach is that it properly pertains to the Zwischenzustand.

Faber advances three lines of thought in support of his thesis. First, souls do not sleep-or, rather, their sleep is such that it does not prevent thinking and recognition. Prima facie, the argument hardly strikes us as convincing, for in everyday sleep we may dream but we do not think and recognise those around us in the ordinary sense of the words. Faber's point is not altogether atypical, however. It is akin to reasoning, also offered by our authors, that the souls are alive after the body's death and, therefore, they must be awake. Both arguments make sense if we add a silently assumed premise, namely, backwards compatibility. People recognised each other on earth; if their souls continue in a conscious existence after death, they must also be able to recognise familiar people. ${ }^{42}$ The logic is articulated in the second argument that since people care for relatives and friends in this life, they will have all the more, and purer, compassion for them once cleansed and liberated from sin. Faber adds two further considerations, one constructive, the other defensive. It is often said when a mother dies soon after the death of her child, Faber observes with approval, that the baby has begged God that she might also come. Defensively, Faber, imitating Specker, takes issue with Augustine's notion that souls in the Zwischenzustand have no compas-

42 Nowhere in the entire corpus is the problem raised as to whether a limit might be set to recognition not so much by the knowing subject as by the object of knowledge in that souls, not bodies, must be recognised. Authors might insist that existence in the interim state is somehow imperfect until the body is reunited with the soul (e.g. Mirus 1590, O3; Pflacher 1589, 273; Weiser 1588, 27f.), but for all practical intents and purposes the soul is assumed to carry complete personhood. 
sion. He also goes beyond his source by questioning the authenticity of $D e$ cura. It is only with the third argument that he turns to scripture. 'He [the rich man] said [to Abraham], "Then, father, I beg you to send him to my father's house - for I have five brothers - that he may warn them, so that they will not also come into this place of torment".' (Luke 16:27-28.) If the damned think of their nearest and dearest, how much more the righteous! ${ }^{43}$

Details of Faber's reasoning such as the locus classicus from the Lukan parable or the Augustinian problem of compassion clearly link his approach to other treatments of souls recognising each other. However, the general direction of his interpretation - that is, the emphasis on thinking of those left behind rather than recognising them when they arrive at the interim abode - will not be picked up by later authors. Faber's approach allows him to combine the interpersonal aspect of epistemology with its specificity for the interim state, but others do not seem to be interested in such a fine point. ${ }^{44}$

There was not much at stake for them in a clear-cut distinction between eternal life and the Zwischenzustand. They were happy to blur the line between the two states. In fact, it seems that they considered earthly existence, the interim state, and post-resurrection life as a series of backwards compatible states, the latter stages entailing all the good qualities of the former and some more. A not insignificant corollary of this view is that the absence of the body in the middle stage is given lip-service at best and is largely ignored analytically. One-if not the-crucial dividing line between the two otherworldly states is the re-assumption of the body in the general resurrection. The fact that the two states are virtually indistinguishable in

43 Note that this is yet another version of the backwards compatibility argument.

44 Frölich is the third author to argue the question in detail $\left(1590,81^{\mathrm{v}}-89^{\mathrm{v}}\right)$. His reasoning, although somewhat narrower in scope, is very similar to Garcaeus's, and their theses are also equally broad. Frölich is also convinced that all the righteous will know each other, and that also better than in this life. He also employs the argument from backwards compatibility, but the bottom line, presented in various forms, is that the redeemed will have perfect knowledge, which necessarily also entails personal recognition. He grounds the claim Christologically via Romans 5:15-19 that Christ has not won back what was lost by Adam, unless the personal aspect of knowledge is also included. Ultimately, creatures - and Frölich is much taken by the prospect of our recognising the angels individually - will be known in God; conversely, the promised perfect knowledge of God logically necessitates our knowledge of angels and humans as well. He selects four prooftexts that he analyses in some detail: Lazarus and Dives from Luke 16, Jesus's transfiguration ostensibly from Matthew 17 (but including the specifically Lukan detail of Jesus's impending death in Jerusalem), the surprise of the damned from Wisdom 5, and Paul's expectation of full knowledge from 1 Corinthians 13. All four passages are familiar from Garcaeus, and the interpretation of the latter two is based on the logic of 'analogous but more perfect'. Nor does Frölich draw a sharp distinction between post-mortem and post-resurrection epistemology. 
sixteenth-century discussions shows that the absence of the body played no major role in early modern writers' reflections on the interim state. With that, we have completed an overview of the source material and can take a step back and draw some conclusions from what we have seen.

\section{Knowledge, body, community}

The literary corpus we have reviewed clearly shows that later sixteenthcentury Lutheran writers were interested in the interim state, and they postulated the soul's conscious survival between the body's death and resurrection. That condition makes the Zwischzustand a special state, and our authors were apparently interested in reflecting on its unique characteristics. The details of their explorations nevertheless hold some surprises. What matters is not only what they say but also what they do not speak about. In this story, omissions are as important as the issues our texts choose to foreground.

The first characteristic to note is that an ontological approach is entirely lacking. There is no discussion of the nature and being of disembodied souls. Their very existence is surely insisted upon, but affirmation is no analysis, and the latter is missing. Instead of their being, our authors are interested in the actions and knowledge of souls. Of these two issues, the latter seems more important, for the texts ascribe no special occupation to disembodied souls. What these descriptions say souls do differs little from what humans are expected to do after the general resurrection, when their souls are reunited with their (glorified) bodies.

If disembodied souls' activities are not helpful in delimiting the postmortem from the post-resurrection state, knowledge could be in at least two ways. First, with the body gone and decomposed, souls have no access to sense perception and should have different means of gaining a knowledge of the outside world. The framework is set up for a discussion of that problem, but our authors never in fact engage in it. The epistemic function of the body is not problematised at all. The same sense perceptions, especially seeing and hearing, are attributed to the 'naked' soul that we normally consider mediated through the body. It is not simply that disembodiment seems not to hinder the souls' access to knowledge, but our authors do not even find the question worth asking. We must be careful, however, how we interpret that omission. It might seem on the surface that the texts treat the body as epistemically disposable, but I suggest that this is not the case. Rather, bodily functions are ascribed to the soul. When the body is gone, 
the soul takes over its epistemic functions. In other words, the body is never relinquished. Sensory language and conceptualisation of sense-based experience still permeate the discussion of ostensibly disembodied knowledge. Knowing, for our authors, is ultimately a function of the body, even if this means 'packing' bodily functions into the soul.

If modes of knowing outside the body are thus not used to characterise the interim state, the content of disembodied souls' knowledge of this world might still provide an access to its special features. This might explain why so much more attention is lavished on how souls know the temporal world than on how they know the Trinity and spiritual beings - a detail worth registering in and of itself. This world and the Zwischenzustand are coterminous. The final conflagration will end both, while God and the angels will continue as objects of knowledge in eternity. Knowing this world is thus a special test case for the interim state. After the resurrection humans can at best remember the world but cannot 'know' it as disembodied souls can. Consequently, one way to delimit the interim state would be to analyse the disembodied souls' knowledge of this world. While in a general sense this is a question that catches the attention of our early modern writers, they do not develop it in the ways we might expect.

Their answer is both limited and uninventive. They simply adopt Augustine's suggestion about the sources of information available to departed souls before the resurrection. They do not contrast those alternatives with the post-resurrection options, although at least one of them-news gathered from newly arriving souls - is certainly unique to the interim state. Rather than using this question to distinguish one ontological condition from the other, authors tend to blur the line between post-mortem and post-resurrection states. The modern, post-Enlightenment, juxtaposition between the immortality of the soul and the resurrection of the body, which twentieth-century Protestant reflection considered so central, does not seem to be shared by Lutheran thinkers of the early confessional era.

Given this general attitude, knowing God outside the body is not contrasted with knowing God in the body, either earthly or resurrected. What is said about knowing God is predicated on the depiction of the heavenly worship in Revelation, and no detailed epistemology of engaging the divine is developed. Significantly, where authors go beyond an affirmation that disembodied souls know the Trinity directly is in declaring that God is foundational for all knowledge: creatures will also be known in God. This signals an indissoluble link between knowing God and knowing others, which leads us to a final point. 
With the exception of the centrality of the body, our findings have been largely negative so far, but there is one aspect of the question that receives particular attention in the texts. The topic that interests sixteenth-century authors most is the possibility of personal recognition in the hereafter. Most of the writers touch on it, and several of them offer sustained discussions of it. Their analysis relies heavily on the Bible, but the choice of the question is not scriptural, for it is itself no more inherently biblical than several other issues that authors choose not to explore. Its motivation must have come from elsewhere. The question is part of the patristic tradition upon which the Reformation also depends, but this again is insufficient reason to explain why it elicited so much interest in the sixteenth century. Another factor may have been the challenges of popular religion such as those to which Frölich responded, but the topic probably also provided an opportunity to address some deep-seated concerns.

The assurance that God is stronger than death and that, despite all appearances, the latter is not able to destroy human personhood completely and irrevocably is a central tenet of Christianity. It obviously underlies the texts I am analysing, but it can be articulated in a variety of ways. When our authors emphasise the continuity of personhood and individual identity beyond the grave by arguing that humans will recognise each other in the hereafter, they do not merely unpack Christ's victory over death. They also reveal their understanding of the preconditions of identity and knowing, in which the human community plays a crucial part. We have seen above that backwards compatibility was an operative principle in the arguments about the interim state. It is based on the assumption that the life to come will be a perfected form of this life. Conversely, what is said of the future state is an expression of the implicit understanding of the present human condition.

Personal recognition is not only a prerequisite of community but also assures individual identity, because recognising others also implies being recognised by others. By confessing an afterlife in which individuals are recognised, family members can reunite, and friends meet again, early modern writers not only express their faith in a God who upholds the core of the human person and overcomes the ultimate isolation of death but also affirm that human personhood is to a large extent constituted in interpersonal relationships. Death is not an individual concern. Beyond destroying the self, it also rends the social fabric. If death is to be overcome, both must be reconstituted, because without the community there is no self. Enjoying God's presence, which the faithful look forward to in the hereafter, cannot be complete without enjoying the company of loved ones. 


\section{Conclusion}

To summarise, when in the second half of the sixteenth century Lutheran authors turned to the question of the individual's fate after death, they also reflected on what and how disembodied souls might know. They did not develop a robust epistemology, however; their approach remained thoroughly Bible-based. Their theory of knowing, such as it was, remained rudimentary, basically adopting an Augustinian view. The way in which they speak of the interim state, employing sensory language in the context of naked souls, betrays the centrality of the body in knowing. The fact that they do not maintain a sharp distinction between the interim state and post-resurrection existence, but rather ascribe qualities of the latter (a reembodied state) to the former is another sign of how difficult they found it to let go of the body.

In terms of what is known, our writers certainly considered direct knowledge of God as an unsurpassable blessing awaiting the faithful after death, yet they were more interested in the details of humans recognising each other. That concern indeed emerges as the other focal point in addition to the indispensability of the body. In the discussion of both how knowledge is acquired and what is known, the other takes centre-stage. The individual's knowledge is constituted interpersonally.

I have examined texts reflecting on the knowledge of the disembodied individual soul, yet the analysis has shown that neither disembodiment nor individuality, at the expense of social interconnectedness, is a simple concept that early modern writers accepted at face value. For them, both the bodily and the social aspects of knowledge in the transcendental, spiritual realm were irreducible. Knowledge is dependent on the sensory apparatus of the body - if the body is not available, the soul has to assume its functions - and embedded in interpersonal relationships. Even when God can be known face to face, the experience cannot be interpreted without reference to the human community. What these texts show us, then, is that for sixteenthcentury minds knowledge of God is irreducibly intertwined with both the body and the human community.

\section{$* * *$}

GÁBOR ITTZÉS is Advisor for Academic Affairs to the Reformation Memorial Committee of Hungary and an affiliate at Károli Gápár University, Budapest.

E-mail: temenos@ittzes.eu 
Abbreviations

ADB Allgemeine Deutsche Biographie, ed. Historische Kommission bei der Königlichen Akademie der Wissenschaften, München, 56 vols., repr. (Berlin: Duncker \& Humblot, 1981) <www.deutsche-biographie.de>.

BBKL Biographisch-Bibliographisches Kirchenlexikon, ed. Friedrich Wilhelm Bautz and Traugott Bautz, 36 vols. to date (Hamm \& Herzberg: Bautz, 1970-) <www.bbkl.de>.

BPal Bibliotheca Palatina: Druckschriften / Stampati Palatini / Printed Books, microfiche ed., ed. Leonard Boyle and Elmar Mittler (Munich: Saur, 1995).

DBA Deutsches biographisches Archiv I-III, microfiche ed. (Munich: Saur, 1999-2002).

DBE Deutsche Biographische Enzyklopädie, 2nd, rev. ed., ed. Bruno Vierhaus, 12 vols. (Munich: Saur, 2005-2008).

LThK Lexikon für Theologie und Kirche, 3rd ed., ed. Walter Kasper et al., 11 vols. (Freiburg i.Br. etc.: Herder, 1993-2001).

NDB Neue Deutsche Biographie, ed. Historische Kommission der Bayerischen Akademie der Wissenschaften, 25 vols. to date (Berlin: Duncker \& Humblot, 1953-) <www.deutsche-biographie.de $>$.

NPNF Nicene and Post-Nicene Fathers: A Select Library of the Christian Church, Series I, 14 vols, ed. Philip Schaff, repr. (Peabody: Hendrickson, 1995).

RGG Religion in Geschichte und Gegenwart: Handwörterbuch für Theologie und Religionswissenschaft, 4th ed., ed. Hans Dieter Betz et al., 9 vols. (Tübingen: Mohr Siebeck, 1998-2007).

RPP Religion Past E Present: Encyclopedia of Theology and Religion, ed. Hans Dieter Betz et al., 14 vols. (Leiden \& Boston: Brill, 2007-2013).

VD16 Verzeichnis der im deutschen Sprachbereich erschienenen Drucke des 16. Jahrhunderts <www.vd16.de>.

Bibliography

Anderson, Gary A.

2011 Is Purgatory Biblical? - First Things 217 (Nov), 39-44.

Brady, Philip V.

1971 Notes on a Preacher's Repertory: Ambrosius Taurer's Bußruffer (1596). - Modern Language Review 66, 826-31.

\section{Bynum, Caroline Walker}

1995 The Resurrection of the Body: In Western Christianity, 200-1336. New York: Columbia UP.

\section{Chyträus, David}

1592 Christlicher, Tröstlicher und in Gottes Wort gegründter unterricht. I. Von 
Unsterbligkeit der Seelen und jhrem Zustand nach dem Leibstodt. II. Von dem Fegefewr. III. Vom Ende der Welt und Auferstehung der Todten. IIII. Vom Jüngsten Gericht. V. Von der Ewigen Marter und Pein der Gottlosen in der Helle. Frankfurt a.d.O.: Johann \& Friedrich Hartmann \& Nikolaus Voltz. (VD16: C 2656.)

\section{Evener, Vincent}

2015 Wittenberg's Wandering Spirits: Discipline and the Dead in the Reformation. - Church History 84, 531-55.

\section{Faber, Basilius}

1572 Tractetlein von den Seelen der Verstorbenen / vnd allem jhrem zustand vnd gelgenheit. - Christliche/nötige ond nützliche vnterrichtungen/von den letzten hendeln der Welt. Auffs new zum fünfften mahl gemehret vnd gebessert, $\mathrm{Y} 1^{\mathrm{r}}-\mathrm{c} 5$ v . Leipzig: Hans Steinmann \& Ernst Vögelin. (VD16: ZV 23365; also available in microform in BPal: F 2433-2435.)

\section{Frank, Günter}

1993 Philipp Melanchthons Idee von der Unsterblichkeit der menschlichen Seele. - Theologie und Philosophie 68, 349-67.

\section{Frölich, Bartholomaeus}

1590 Seelen Trost/ Das ist/ [C]hristlicher bericht vom Zustande vnd Glück der lieben Seelen/ in jener Welt/ biß an den jüngsten Tag. 2. Vnd das gleubige Christen keine Vrsach haben / sich für dem Tode oder Sterben zu fürchten. 3. Auch wie die Seelen seliglich abscheiden/ ond der Mensch in seinem Todskampff wider alle Anfechtung bestehen kan. 4. Jtem/ Was der Mensch für Gedancken in seiner letzten Hinfarth haben / vnd wie er sich verhalten sol. 5. Schließlichen/Ob wir einander auch in jener Welt kennen vnd ansprechen werden. Sampt sehr schönen Gebetlein/ aus Göttlicher Schrifft Reimweise gestellet/in Sterbens vnd andern Nöthen zu beten gantz tröstlich. Leipzig: Johann Beyer. (VD16: F 3066.)

\section{Garcaeus, Johannes Jr.}

1573 Sterbbüchlein Darin Von den Seelen/ jrem ort/ standel thun und wesen / aller Menschen/bis an den Jüngsten tag/aus Gottes wort vnd der lieben Veter Schrifften/ warhafftiger bericht. Wittenberg: Peter Seitz. (VD16: G 461; also available in microform in BPal: F 720-721.)

\section{Ittzés, Gábor}

2014 Somnus mortis imago: Az alvás mint a halál metaforája a 16. század második felének német evangélikus teológiájában. - Theologiai Szemle n.s. 57, 196-205.

2015a The Renewal of the Immortality Doctrine in the Reformation: The Case of Martin Mirus, Gregor Weiser, and Moses Pflacher. - Bulcsú K. Hoppál (ed.), Theories and Trends in Religions and in the Study of Religion: Selected Papers of the $10^{\text {th }}$ Conference of the European Association for the Study of Religions, 61-85. Budapest: L'Harmattan. 
2015b Text and Subtext: Johannes Garcaeus' Sterbbüchlein and Melchior Specker's Vom Leiblichen Todt: A Study in Early Modern Literary Borrowing. - German Life and Letters 68, 335-55.

2016 The Legacy of a Strasbourg Preacher: Melchior Specker's Vom Leiblichen Todt as an Unknown Source of Basilius Faber's Tractetlein von den Seelen der Verstorbenen. - Journal of Early Modern Christianity 3, 239-69.

\section{Le Goff, Jacques}

1984 The Birth of Purgatory, trans. Arthur Goldhammer. Chicago: University of Chicago Press.

\section{Lohse, Bernhard}

1999 Martin Luther's Theology: Its Historical and Systematic Development, trans. Roy A. Harrisville. Minneapolis: Fortress.

Malý, Tomáš

2015 Early Modern Purgatory: Reformation Debates and Post-Tridentine Change. - Archiv für Reformationsgeschichte 106, 242-72.

\section{Melanchthon, Philip}

1544 Commentarius de anima. Strasbourg: Kraft Müller. (VD16: M 2753.)

1988 On the Soul [abridged ET of Liber de anima (1553)]. - A Melanchthon Reader, trans. Ralph Keen, 239-89. New York etc.: Peter Lang. - For a full Latin text, see Corpus Reformatorum, Series I: Philippi Melanchthonis Opera quae supersunt omnia, 28 vols., ed. Karl G. Bretschneider \& Heinrich E. Bindseil, 13:5-178. Halle: Schwetschke \& Sohn, 1834-1860.

\section{Mirus, Martin}

1590 Sieben[ ]Christliche Predigten Auff dem Reichstage zu Regenspurg gethan I als Anno 1575. vnser aller Gnedigster Keiser Rudolphus II. zum Reich erwehlet worden / etc. Dorinnen die furnemesten Artickel vnser waren Christlichen Religion ausführlich erkleret/ ond die jrrige Meinung falscher Lehre vnd Abgötterey des Bapstums mit sattem Grunde widerleget worden. Erfurt: Esaias Mechler. (VD16: M 5471.)

\section{Musculus, Andreas}

1565 Gelegenheit / Thun wnd Wesen der Verstorbenen /von jrem Abschied an / aus diesem Leben / bis zum eingang / nach gehaltenem Jüngsten Gericht / zum ewigen Leben. Frankfurt a.d.O.: Johann Eichorn. (VD16: M 7151; also available in microform in BPal: F 522-523.)

\section{Pflacher, Moses}

1589 Die gantze Lehr Vom Tod vnd Absterben des Menschen/ in ein richtige ordnung Kurtz verfasset/ ond gepredigt. [Herborn:] Christoph Rab. (VD16: P 2388.)

\section{Specker, Melchior}

1560 Vom Leiblichen Todt. Was er sey/waher er kom[m]e/vnd wie man sich darzu 
bereyten solle/ Auch Von der Begräbniß vñ Begäncknussen/vnd wie man sich der Abgestorbenen halben trösten vnd halten solle. Jtem Von der Selen vnd jrem ort/ stand/ ond wesen/biß auff den Jüngsten tag. Alles auß H. Schrifft/ vnd der Vätter außlegung / fleyssig züsam[m]en gebracht. Strasbourg: Samuel Emmel. (VD16: S 8169; also available in microform in BPal: F 3819-3820.)

\section{Thiede, Werner}

1982 Luthers individuelle Eschatologie. - Luther Jahrbuch 49, 7-49.

1993 Nur ein ewiger Augenblick: Luthers Lehre vom Seelenschlaf zwischen Tod und Auferweckung. - Luther: Zeitschrift der Luther-Gesellschaft 64, 112-25.

\section{Tripp, David}

1997 The Image of the Body in the Formative Phases of the Protestant Reformation. - Sarah Coakley (ed.), Religion and the Body, 131-52. Cambridge: Cambridge UP.

\section{Weiser, Gregor}

1588 Christlicher Bericht/Von Vnsterbligkeit und Zustand der Seelen nach jhrem Abschied/ Vnd letzten Hendeln der Welt. Sampt gründlicher vnd ausführlicher erklerung aus den Schrifften der Veter/ Jtem Herrn D.MATRINI LVTHERI, Iohannis Mathesii, D.Martini Miri, vnd Iohannis Gigantis, Jn Frag vnd Antwort. Eisleben: Andreas Petri \& Leipzig: Henning Grosse. (VD16: W 1584.) 
